\title{
Epidemiologic Study of Zoophilic Dermatophytoses between 2010 and 2016
}

\author{
Su Jung Kim \\ Department of Biomedical Laboratory Science, Daegu Health College, Daegu, Korea
}

\section{2016년 동안 동물친화성 피부 사상균 감염의 역학적 연구}

김수정

대구보건대학교 임상병리과

\begin{abstract}
In recent years, change in life patterns gave rise to an increase in the number of families with companion animals, and as a result, frequent dermatophytes infections have been reported. Microsporum canis, Trichophyton mentagrophytes, and Trichophyton verrucosum, are among these species of zoophilic dermatophytes. Trichophyton mentagrophytes are transmitted to humans by contact with wild animals. Infection from it causes strong inflammation in humans. Conversely, Trichophyton verrucosum is transmitted by contact with cattles. Microsporum canis will become latent carriers in cats or dogs, causing infectious diseases when it comes in contact with humans. We investigated zoophilic dermatophytes isolated according to annual, sex, age, season, body sites, and clinical types between 2010 and 2016. According to our results, the isolation rate of zoophilic dermatophytes was $0.37 \%$, among which, 88 T. mentagrophytes, 228 Microsporum canis, and 18 Trichophyton verrucosum were isolated in human. It is interesting to note that Microsporum canis has been on the rise since 2014. Microsporum canis and Trichophyton verrucosum were highly isolated in females, but $T$. mentagrophytes was isolated similarly in both sexes. According to an age-based survey, the isolation rate was higher in children younger than 10 years. Our results is a valuable data for predicting and studying the isolation of zoophilic dermatophytes in the future.
\end{abstract}

Key words: Zoophilic, M. canis, Dermatophytoses

This is an Open Access article distributed under the terms of the Creative Commons Attribution Non-Commercial License (http://creativecommons.org/licenses/by-nc/4.0) which permits unrestricted non-commercial use, distribution, and reproduction in any medium, provided the original work is properly cited.

Copyright (C) 2017 The Korean Society for Clinical Laboratory Science. All rights reserved.
Corresponding author: Su Jung Kim Department of Biomedical Laboratory Science, Daegu Health College, Youngsong-ro, Daegu, 41453, Korea

Tel: 82-53-320-1303

Fax: 82-53-320-1450

E-mail: sjkim4238@hanmail.net

Received: October 18, 2017

Revised $1^{\text {st: }}$ : November 2, 2017

Revised 2 ${ }^{\text {nd }}$ : November 7, 2017

Revised $3^{\text {rd. }}$ : November 9, 2017

Accepted: November 9, 2017

\section{서 론}

사람과 동물의 피부질환으로 가장 빈번하게 나타나는 것 중 하나가 피부사상균 감염에 따른 곰팡이성 질환이 있으며 이는 크게 인체 친화성, 동물친화성, 토양친화성으로 나뉠 수 있다 [1-3]. 사회구조의 변화와 생활수준의 향상으로 애완동물의 개 념을 넘어 반려동물의 시대가 초래하였다. 동물보호 국민의식 조사에 의하면 2015년도 국내 반려동물을 키우는 가구수가 약
457만(21.8\%) 가구로 조사되었다[4]. 이런 사회적인 변화로 다 양한 동물들을 가족의 범주로 생각하는 추세이기에 반려동물 등의 접촉으로 인한 인체 질환도 증가하고 있다. 그 중 대표적인 경우가 동물친화성 피부사상균에 의한 감염이며 동물친화성 피 부사상균 감염은 인체 친화성 피부사상균감염에 비해 심한 염 증을 수반하는 것으로 보고가 되고 있다[3,5-7]. 동물 친화성 피 부사상균의 균종은 Microsporum canis (M. canis), Trichophyton mentagrophytes var mentagroghytes (T. menta- 
grophytes), Trichophyton verrucosum (T. verrucosum) 등 이 있다[8,9]. M. canis는 주로 고양이나 개가 피부사상균을 잠 복하고 있으면서 사람과의 접촉에 의해 감염되거나 동물을 사 육 시 동물에 의해 침구, 의복이 오염되어 사람에게 전파된다 [10-12]. T. mentagroghytes는 야생동물 접촉에 의해 인체로 전파되며 인체에 감염 시 강한 염증을 유발하고 두부, 체부, 수 발, 얼굴에 백선을 일으키는 것으로 알려져 있다[13,14]. T. verrucosum은 소의 백선유발균종으로 알려져 있으며 대부분 소와의 접촉으로 감염을 일으키고 얼굴 체부, 두부백선 등을 일 으키는 것으로 알려져 있다[15]. 동물친화성 피부사상균 감염 에 대한 보고는 Roh 등[16]이 1993 1994년내 동물친화성 피 부사상균 감염을 대상으로 역학조사를 시작하게 되었으며 Bang과 Kim [1], Bang 등[2]에 의해 1995 2004년, 2005 2010년까지 동물친화성 피부사상균의 감염보고가 이어지고 있다. 그러나 최근 2010 2016년 발표자료의 부족으로 본 연 구자는 대구소재의 가톨릭 피부과의원에서 분리된 동물친화성 피부사상균 감염 자료를 통해 균종에 따른 연도별, 성별, 계절, 연령, 부위별 및 임상 질환별 분리분포를 분석하여 보고 하고자 한다.

\section{재료 및 방법}

\section{1. 연구 대상}

2010년 1월부터 2016년 12월까지 대구시 소재의 가톨릭 피 부과의원을 통해 임상적 소견, $20 \% \mathrm{KOH}$ 검사 및 진균배양 검사 를 통해 피부사상균으로 진단된 환자의 자료를 의뢰 받아 분석 하였다. 환자의 의무기록지를 이용하여 후향적 조사를 수행하
였으며 연도별, 성별, 연령별, 계절별, 부위별, 질환별 분포에 대 해 조사하였다.

\section{2. 진균학적 검사}

진균증은 $\mathrm{KOH}$ 검사로 확인하며 검사방법은 환자병원부위 를 $70 \%$ 알코올로 소독 후 검체를 채취하여 $20 \% \mathrm{KOH}$ 를 처리한 후 균사를 광학현미경으로 관찰하였다. 진균 배양과 동정을 위 해 potato dextrose agar배지에 접종한다. $25^{\circ} \mathrm{C}$ 에서 2 주간 배 양한 후 배양된 집락을 육안적 관찰한 뒤 lactophenol cotton blue로 염색하여 현미경으로 균사, 분생자 및 대분생자를 관찰 하여 원인균을 최종 동정하였다[1].

\section{3. 통계 처리}

통계 처리를 위하여 SPSS version 21.0 (SPSS, New York, USA)를 이용하였으며 통계 처리된 결과의 유의수준은 $p$-value 가 0.05 미만인 경우를 통계적 유의성을 가진다고 하였다.

\section{결 과}

\section{1. 연도별 피부사상균의 분포}

2010 2016년도에 병원을 내원한 환자를 대상으로 $\mathrm{KOH}$ 직접도말 검사를 실시한 결과 총 90,152 명의 양성환자를 대상 으로 potato dextrose agar배지에 접종하고 LPCB로 염색하여 현미경으로 관찰하여 동정된 결과를 분석하였다. 분석 결과 전 체 분리균은 인체 친화성 감염환자는 33,575 명으로 $37.24 \%$ 가 분리되었으며 동물친화성에 감염된 환자는 334명으로 $0.37 \%$ 가 분리되었다. 토양친화성에 감염환자는 30 명으로 $0.03 \%$ 가

Table 1. Annual distribution of dermatophytes isolated during 2010 2016

\begin{tabular}{|c|c|c|c|c|c|c|c|}
\hline \multirow{2}{*}{ Species } & \multicolumn{7}{|c|}{ Year } \\
\hline & 2010 & 2011 & 2012 & 2013 & 2014 & 2015 & 2016 \\
\hline \multicolumn{8}{|l|}{ Anthropophiilic dermatophytes } \\
\hline T. rubrum & 4,549 & 4,209 & 4,614 & 4,689 & 4,424 & 4,330 & 5,147 \\
\hline E. floccosum & 11 & 6 & 3 & 4 & 4 & 3 & 3 \\
\hline T. tonsurans & 3 & 7 & 3 & 4 & 17 & 7 & 6 \\
\hline T. mentagrophytes var.interdigitale & 260 & 268 & 273 & 215 & 205 & 227 & 88 \\
\hline \multicolumn{8}{|l|}{ Zoophilic dermatophytes } \\
\hline T. mentagrophytes var. mentagrophytes & 27 & 19 & 14 & 1 & 14 & 7 & 6 \\
\hline T. verrucosum & 1 & 4 & 9 & 0 & 2 & 0 & 2 \\
\hline M. canis & 20 & 21 & 17 & 18 & 52 & 40 & 60 \\
\hline \multicolumn{8}{|l|}{ Geophilic dermatophytes } \\
\hline M. gypsenm & 7 & 6 & 2 & 4 & 5 & 2 & 4 \\
\hline No growth and contamination & 9,989 & 7,491 & 7,140 & 7,560 & 7,874 & 8,382 & 7,781 \\
\hline Total & 14,867 & 12,031 & 12,075 & 12,487 & 12,597 & 12,998 & 13,097 \\
\hline
\end{tabular}

Abbreviations: T, Trichophyton; E, Epidermophyton; M, Microsporum. 
분리되었고 그 외에 배양이 되지 않거나 오염균이 56,217 명으 로 $62.35 \%$ 가 분리되었다(Table 1).

\section{2. 성별 동물친화성 피부사상균의 분포}

피부사상균 중 동물친화성 피부사상균 3균종을 대상으로 남 녀 분포를 살펴 본 결과 T. mentagrophytes는 총 88 명이 분리 되었으며 남자와 여자가 각각 45 명(51.1\%) 43 명(48.9\%)으로 성별에 연관성은 거의 없었다. T. verrucosum은 총 18 명이 분 리되었으며 남자(7명, 38.9\%)에 비해 여자(11명, 61.6\%)가 다 소 높게 분리되었다. M. canis는 총 228 명이 분리되었고 여자 (174명, $76.3 \%)$ 에서 남자(54명, 23.7\%)에 비해 높은 분리율을 보였다(Table 2).

\section{3. 연령별 동물친화성 피부사상균의 분포}

연령에 따른 피부사상균 3 균종을 분석해 본 결과 $T$. mentagrophytes는 50대(23명, 26.4\%)가분리되었고 60대(14 명, $16.1 \%)$ 로 높게 분리되었고 40 대와 10 대 미만에서 각각(10 명, 11.5\%) 10대(9명, 10.3\%), 70대 이상(8명, 9.2\%), 그리고 20대(6명, 6.9\%)와 30대(7명, 8.0\%)로 분리되었다. T. verrucosum은 50대(5명, 27.8\%), 60대(3명, 16.7\%), 그리고 10대 미만(3명, 16.7\%)로 높게 분포하였다. M. canis는 10대 미만 (44명, 19.4\%), 10대(50명, 22.0\%)로 분리되었으며 그리고 20 대(34명, 15.0\%)로 높게 분포하였다(Table 3).

Table 2. Gender distribution of zoophilic dermatophytes isolated during 2010 2016

\begin{tabular}{lccc}
\hline \multirow{2}{*}{ Gender } & \multicolumn{3}{c}{ Species } \\
\cline { 2 - 4 } & T. mentagrophytes & T. verrucosum & M. canis \\
\hline Male (\%) & $45(51.1)$ & $7(38.9)$ & $54(23.7)$ \\
Female (\%) & $43(48.9)$ & $11(61.1)$ & $174(76.3)$ \\
Total (\%) & $88(100.0)$ & $18(100.0)$ & $228(100.0)$ \\
\hline
\end{tabular}

Table 3. Age distribution of zoophilic dermatophytes isolated during 2010 2016

\begin{tabular}{lccc}
\hline \multirow{3}{*}{ Age group } & \multicolumn{3}{c}{ Species } \\
\cline { 2 - 4 } & T. mentagrophytes & T. verrucosum & M. canis \\
\hline $1 \sim 10$ & $10(11.5)$ & $3(16.7)$ & $44(19.4)$ \\
$11 \sim 20$ & $9(10.3)$ & $1(5.6)$ & $50(22.0)$ \\
$21 \sim 30$ & $6(6.9)$ & $2(11.1)$ & $34(15.0)$ \\
$31 \sim 40$ & $7(8.0)$ & $1(5.6)$ & $18(7.9)$ \\
$41 \sim 50$ & $10(11.5)$ & $2(11.1)$ & $18(7.9)$ \\
$51 \sim 60$ & $23(26.4)$ & $5(27.8)$ & $21(9.3)$ \\
$61 \sim 70$ & $14(16.1)$ & $3(16.7)$ & $13(5.7)$ \\
$\geq 70$ & $8(9.2)$ & $1(5.6)$ & $29(12.8)$ \\
Total & $88(100.0)$ & $18(100.0)$ & $228(100.0)$ \\
\hline
\end{tabular}

\section{4. 계절별 동물친화성 피부사상균의 분포}

계절에 따른 피부사상균 3균종을 분석한 결과 T. mentagrophytes는 봄(30명, 34.1\%)과 겨울(26명, 29.5\%)에 높게 분 리되었고 T. verrucosum은 봄(8명, $44.4 \%)$ 이 가장 높게 분리 되었으며 겨울 (5명, $27.8 \%)$ 에 다소 높게 분리되었다. M. canis 는 봄(43명, $18.9 \%)$, 여름(62명, 27.2\%), 가을(59명, 25.9\%), 그 리고 겨울(64명, 28.1\%)이 사계절이 비슷하게 분리되었다. 이 는 T. mentagrophytes와 T. verrucosum은 계절에 따라 연관 성을 보이나 M. canis는 계절에 따른 연관성이 나타나지 않았다 (Table 4).

\section{5. 부위별 동물친화성 피부사상균의 분포}

분리된 부위에 따른 피부사상균 3 균종을 분석한 결과로 $T$. mentagrophytes는 얼굴(25명, 28.4\%), 팔(22명, 25.0\%)로 높 게 분리되었으며 T. verrucosum도 얼굴(7명, 38.9\%), 팔(5명, $27.8 \%)$ 이 높게 분리되었다. 그러나 M. canis는 다소 다양하게 머리(56명, 24.5\%), 팔(49명, 21.5\%), 얼굴(36명, 15.8\%), 등 (29명, 12.7\%) 등의 순으로 높게 분리되었다(Table 5).

Table 4. Seasonal distribution of zoophilic dermatophytes isolated during 2010 2016

\begin{tabular}{lccc}
\hline \multirow{2}{*}{ Season } & \multicolumn{4}{c}{ Species } \\
\cline { 2 - 4 } & T. mentagrophytes T. verrucosum & M. canis \\
\hline Spring (Mar May) & $30(34.1)$ & $8(44.4)$ & $43(18.9)$ \\
Summer (Jun $\sim$ Aug) & $17(19.3)$ & $2(11.1)$ & $62(27.2)$ \\
Autumn (Sep Nov) & $15(17.0)$ & $3(16.7)$ & $59(25.9)$ \\
Winter (Dec Feb) & $26(29.5)$ & $5(27.8)$ & $64(28.1)$ \\
Total & $88(100.0)$ & $18(100.0)$ & $228(100.0)$ \\
\hline
\end{tabular}

Table 5. Distribution in body sites of zoophilic dermatophytes isolated during 2010 2016

\begin{tabular}{lccc}
\hline \multirow{2}{*}{ Body site } & \multicolumn{3}{c}{ Species } \\
\cline { 2 - 4 } & T. mentagrophytes & T. verrucosum & M. canis \\
\hline Scalp & $1(1.1)$ & $0(0.0)$ & $56(24.5)$ \\
Face & $25(28.4)$ & $7(38.9)$ & $36(15.8)$ \\
Neck & $3(3.4)$ & $0(0.0)$ & $18(7.9)$ \\
Chest & $4(4.6)$ & $2(11.1)$ & $18(7.9)$ \\
Back & $2(2.3)$ & $2(11.1)$ & $29(12.7)$ \\
Arms & $22(25.0)$ & $6(33.3)$ & $49(21.5)$ \\
Legs & $12(13.6)$ & $0(0.0)$ & $10(4.4)$ \\
Hands & $10(12.5)$ & $1(5.6)$ & $8(3.5)$ \\
Foods & $8(9.1)$ & 0 & $2(0.9)$ \\
Groin & $0(0.0)$ & 0 & $2(0.9)$ \\
Total & $88(100.0)$ & $18(100.0)$ & $228(100.0)$ \\
\hline
\end{tabular}


Table 6. Distribution of clinical types of zoophilic dermatophytes isolated during 2010 2016

\begin{tabular}{lccc}
\hline \multirow{2}{*}{ Clinical type } & \multicolumn{3}{c}{ Species } \\
\cline { 2 - 4 } & T. mentagrophytes & T. verrucosum & M. canis \\
\hline Tinea capitis & $1(1.1)$ & $0(0.0)$ & $56(24.5)$ \\
Tinea facial & $25(28.4)$ & $7(38.9)$ & $36(15.8)$ \\
Tinea corporis & $43(48.9)$ & $10(55.6)$ & $124(54.4)$ \\
Tinea cruris & $0(0.0)$ & $0(0.0)$ & $2(0.9)$ \\
Tinea manus & $10(11.4)$ & $1(5.5)$ & $5(2.2)$ \\
Tinea pedis & $8(9.1)$ & $0(0.0)$ & $2(0.9)$ \\
Tinea unguium & $1(1.1)$ & $0(0.0)$ & $3(1.3)$ \\
Total & $88(100.0)$ & $18(100.0)$ & $228(100.0)$ \\
\hline
\end{tabular}

\section{6. 임상 질환별 동물친화성 피부사상균의 분포}

임상 질환별 분류를 살펴보면 T. mentagrophytes는 몸백선 증(43명, $48.9 \%)$ 이 많이 분리되었고 다음으로 얼굴백선증 $(25$ 명, $28.4 \%$, 수부백선증(10명, $11.4 \%)$ 이 다소 많이 분리되었다. T. verrucosum는 몸백선증 $(10$ 명, $55.6 \%)$ 이 가장 많이 분포하 였고 얼굴백선증(7명, 38.9\%)이 분리되었다. M. canis는 몸백 선증(124명, $54.4 \%)$ 이 가장 많이 분리되었고 두부백선증 $(56$ 명, $24.5 \%$ ), 얼굴백선증(36명, $15.8 \%)$ 이 다소 많이 분리되었다 (Table 6).

\section{고 찰}

전세계적으로 고도의 산업화와 고령화, 그리고 1 인가구의 증 가로 인해 반려동물의 개념이 새롭게 정의되고 있으며 반려동 물이 가족의 일원으로 빠르게 자리잡고 있는 실정이다[4]. 이런 사회적인 분위기를 통해 새로운 동물관련의 고용창출이 이어지 고 있는 반면 또 다른 문제점인 인수공통감염을 유발하는 미생 물들로 인해 감염이 증가되고 있다[10]. Choi 등[12] 의 연구에 의하면 사육하는 개와 고양이의 M. canis의 보균상태를 조사하 였으며 그 결과 가정사육에서는 개는 $7.7 \%$, 고양이는 $20.1 \%$ 이 며 집단사육장에서는 개는 $16.0 \%$, 고양이는 $46.0 \%$ 로 조사하였다. 이에 본 연구진은 2010년에서 2016년도에 동물친화성 피부 사상균 감염의 역학적 조사 및 과거 분리율을 비교하여 분석하 고자 한다. Roh 등[16]의 연구에 의하면 1993 1994년, 2년간 경상도 일부 지역에서 동물친화성 피부사상균의 역학적 조사를 실시하였으며 T. mentagrophytes는 동물접촉과는 유의성이 없음을 보고하였고 M. canis는 애완동물 보유환자에서 높게 분 리됨을 보고 하였으며 T. verrucosum은 소의 접촉에 의해 감염 됨을 보고하였고, 연령별로는 15세 이하인 소아에서 분리율이 높게 나타났으며 부위로는 머리와 얼굴에서 높게 분리되었음을
보고하였다. Choe 등[15]의 연구에 의하면 T. verrucosum의 감염에 대해 보고하였으며 그 결과 계절에 유의성을 나타냈으 며 봄이 가장 높게 분리되고 다음으로 겨울, 여름, 가을의 순으 로 분리되었음을 보고 하였다. 호발 부위는 얼굴이 가장 많으며 팔, 몸체, 두부, 다리 등의 순으로 분리됨을 보고하였다. 남녀의 비율로는 여자가 남자보다 다소 많이 분리되었으며 연령별로는 10 세 미만이 많음을 보고 하였다. 본 연구와 비교하였을 때 기간 은 다르나 T. verrucosum의 감염은 계절별, 성별, 부위별이 동 일하게 분리됨을 알 수 있었다. Bang과 Kim [1]의 연구에 의하 면 1995 2004년에 분리된 동물친화성 피부사상균의 감염에 대해 보고 하였으며 그 결과 동물친화성 피부사상균은 전체 피 부사상균 중 $1 \%$ 를 차지하였고 동물친화성 피부사상균 중 $T$. mentagrophytes는 $46.7 \%$, M. canis는 49.1\%, 그리고 T. verrucosum은 4.2\%로 분포하였으며 연령에 따른 분포는 $T$. mentagrophytes는 10대 미만(32.2\%)에서 가장 높게 나타났 고 10대(16.4\%)와 30대(12.7\%), 40대(11.1\%)의 순서로 분포 하였다. M. canis는 10대 미만(54.1\%)에서 가장 높게 나타났으 며 10대(12.7\%)에서 높게 나타났다. T. verrucosum도 역시 10 대 미만(30.4\%)에서 가장 높게 나타났으며 10대(17.9\%), 30대 (16.1\%), 40대(16.1\%)에서 고르게 분리됨을 보고하였다. 임상 질환별로는 T. mentagrophytes는 얼굴백선(48.6\%)이 가장 높 게 나타났고 체부백선(34.6\%)이 다음으로 높게 나타났다. $M$. canis는 두부백선(41.6\%)이 가장 높게 나타났고 체부백선 (32.7\%), 얼굴백선(20.8\%)이 높게 나타났다. T. verrucosum은 체부백선(41.9\%)이 가장 높게 나타났고 얼굴백선(32.1\%), 두 부백선(19.6\%)의 순으로 높게 나타났다. 계절에 따른 분포는 $T$. mentagrophytes는 겨울(32.0\%)이 가장 높으며 다음으로 봄 (29.0\%), 여름(20.5\%), 가을(18.3\%)의 순으로 비슷하게 분리되 었다. M. canis는 계절에 거의 유의성이 없었으며 T. verucosum 은 봄(37.5\%)이 가장 높게 분리되었고 겨울( $28.6 \%)$ 이 높게 분 리됨을 보고하였다.

Bang 등[2]의 연구에 의하면 2005 2009년에 분리된 동물 친화성 피부사상균의 감염에 대해 보고 하였으며 그 결과로는 전체 피부사상균에 비해 동물 친화성 피부사상균은 $0.75 \%$ 가 분 리되었으며 동물친화성 피부사상균 중 T. mentagrophytes는 $45.0 \%$, M. canis는 $53.5 \%$, 그리고 T. verrucosum은 $1.5 \%$ 로 분 포하였다. 연령에 따른 분포는 T. mentagrophytes는 40대 (18.0\%), 50대(17.2), 60대(17.2\%), 10대 미만(12.3\%), 10대 (12.3\%) 등에서 고르게 분포하였으며. M. canis는 10대 미만 (34.4\%)에서 높게 분리되었고 다음으로 10 대(16.6\%)가 다음 순으로 분리되었다. T. verrucosum은 분리된 균 수가 적어(4명 
에서 분리) 연령에 따른 분포와 관련성을 알기 어려웠다. 임상 질환별로는 T. mentagrophytes는 체부백선(41.0\%)이 가장 많 이 분리되었고 얼굴백선(30.3\%)의 순서로 분리되었다. $M$. canis는 체부백선(43.4\%)이 가장 높게 나타났고 두부백선 (34.4\%), 얼굴백선(15.9\%)의 순서로 분리되었다. T. verrucosum 은총 4건이 분리되었으며 모두 체부백선에서 분리되었다. 계절 에 따른 분포로는 T. mentagrophytes는 봄(33.6\%)이 가장 많 이 분리되었으며 다음으로 겨울(30.3\%)이 많이 분리되었다. $M$. canis는 4계절 모두 비슷한 분리분포를 나타냈으며 T. verrucosum은 총 4 명 중 가을이 3 명으로 분리되고 겨울이 1 명이 분 리됨을 보고하였다. 1995 2004년까지의 조사가 발표된 Bang 과 $\operatorname{Kim}$ [1]의 논문과 2005년에서 2009년까지의 조사가 발표 된 Bang [2]의 논문을 본 연구 내용과 비교해 보았다. 1995 2004년에는 동물친화성 피부사상균이 1\%가 분리되었고 2005 2009년에는 $0.75 \%$ 가 분리되어 점차 감소하는 경향을 보였고 본 연구(2010 2016년)에서도 $0.37 \%$ 로 분리되어 감소하였 다. 동물친화성 피부사상균 중 균종에 따른 분리율을 살펴보면 T. mentagrophytes는 연구시기별로 $46.7 \%, 45 \%, 26.3 \%$ 로 점 차 감소하는 추세이나 M. canis는 49.1\%, 53.5\%, 68.3\%로 점차 증가하는 추세이다. T. verrucosum은 $4.2 \%, 1.5 \%, 5.4 \%$ 로 분 리되었으나 2005-2009년의 조사에서는 분리건수(4건)가 부 족하여 증감을 언급하기가 어려웠다. Lim 등[14]과 Nenoff 등 [7]은 M. canis의 증가의 원인은 개와 고양이의 사육과 야생동 물의 가정내 사육으로 인해 직접적 접촉으로 감염을 유발함을 보고하였으며 이는 다른 동물친화성 진균과는 달리 M. canis의 감염이 증가하는 추세임을 유추할 수 있었다. Seebacher 등[9] 에 의하면 최근 유럽에서도 동물친화성 피부사상균중 M. canis 가 증가하고 있으며 특히 어린이의 두부백선에 가장 많이 분리 됨을 보고하였다. Jang 등[17]은 M. canis의 분리분포에 대한 보고에 따르면 2001 2010년까지 전남지역의 M. canis감염 증을 대상으로 조사한 결과, 연도별에는 큰 변화가 없었으며 연 령별로는 10대 미만에서 $51.1 \%$ 로 높았고 두부백선이 $74.7 \%$ 를 차지한다고 보고하였다. 계절별로는 겨울이 가장 많이 분리되 었고 봄이 다음으로 높게 분리됨을 보고하였다. Jang 등의 결과 를 Bang 등의 2005년 보고와 비교해 보면 10대 미만에서 $51.1 \%, 54.1 \%$ 로 유사하게 분리되었으며 두부백선이 $74.7 \%$, 41.6\%로 높게 분리됨을 알 수 있었다[4,17]. M.canis의 년도별 분리변화를 살펴보면 1995 2013년까지 년도에는 변화가 없 었으나 2014년부터 점차 증가하였다. 이는 사회변화에 따른 고 령화, 단일가족구성으로 인해 애완동물 및 야생동물의 사육이 증가하는 것으로 감염을 유추할 수 있다. 연령에 따른 조사를 비
교해보면 T. mentagrophytes는 1995 2004년에 10대 미만 (32.2\%)에서 많이 분리되었으나 2005 2010년에는 본 연구결 과와 마찬가지로 10 대 미만(12.3\%, 11.5\%)보다는 50 대 $(17.2 \%, 26.4 \%), 60$ 대( $17.2 \%, 16.1 \%)$ 에서 조금 더 높게 분리되 었다. M. canis에서는 1995-2010년까지는 10대 미만(54.1\%, $34.4 \%)$ 에서 많이 분리되었으나 본 연구에서는 10 대 미만 (19.4\%)과 10대(22.0\%)에서 비슷하게 분리됨을 알 수 있었다. T. verrucosum은 1995 2004년에 10대 미만(30.4\%)이 분리 율이 높았으나 2005 2010년에는 총 4건으로 분석이 어려웠 고 본 연구에서는 50 대( $27.8 \%)$ 에서 다소 분리율이 높았으며 그 다음으로 10대 미만(16.7\%)으로 나타났다[1,2].

임상 질환별 비교에서는 T. mentagrophytes가 1995 2004년에 얼굴백선(48.6\%), 체부백선(34.6\%)의 순서로 높게 분리되었으나 2005년 2010년과 본 연구에서는 체부백선 (41.0\%, 48.9\%), 얼굴백선(30.3\%, 28.4\%)의 순서로 분리율이 높게 나타났다. M. canis는 1995 2004년에 두부백선(41.6\%), 체부백선(32.7\%)의 순으로 높게 분리되었으나 2005년 2010 년과 본 연구에서는 체부백선(43.4\%, 54.4\%), 두부백선(34.4\%, 24.5\%)의 순으로 분리되었다. T. verrucosum은 1995 2004 년에 체부백선(42.9\%), 얼굴백선(32.1\%)의 순으로 많이 분리 되는 반면, 2005 2010년에는 체부백선에서만 분리되어 본 연 구결과는 1995 2004년 기간 동안에 분리된 것과 동일하게 분 리되었다. 이는 2005 2010년에 T. verrucosum의 분리수가 총 4건이었기에 분석하기에 부족하다고 판단된다[1,2]. 계절에 따른 비교에서는 T. mentagrophytes가 1995-2004년에 겨울 (32.1\%)과 봄(29.0\%)의 순서로 많이 분리되었으나 2005 2010년과 본 연구에서는 봄(33.6\%, 34.1\%)과 겨울(30.3\%, 29.5\%)의순서로 분리되었고 M. canis는 1995 2004년, 2005 2010년 그리고 본 연구결과를 비교해보면 사계절이 비슷하게 분포하였다[1,2].

Gallo 등[18]의 연구에 의하면 애완동물인 Marmot에 의해 동물친화성 피부사상균이 감염됨을 보고하였으며 이로 인해 $T$. mentagrophytes와 M. canis를 분리되었고 애완동물의 특성 상 계절에 따른 유의성은 거의 없다고 보고하였다. Sadeghi 등 [19]의 연구에 의하면 2014 2015년간 피부사상균에 감염된 134 명의 환자에서 분리된 12 균종을 대상으로 조사한 결과 임 상 질환별로는 두부백선이 $91.6 \%$ 이며 조갑백선이 $8.4 \%$ 로 나 타났으며 남녀 성별에 대한 유의성은 없으며 동물친화성 피부 사상균의 분리율은 M. canis 가 $50 \%$ 로 분리되었고 T. verrucosum 가 25\%, T. mentagrophytes 가 $25 \%$ 로 분리됨을 보고하 였다. Sadeghi 등에 의한 보고에서는 T. verrucosum의 분리율 
이 국내 보고와는 달리 높게 나타남을 확인하였으며 이는 이란 이라는 지역적 특징에 따른 것으로 분석된다.

기존의 피부사상균 분리동정방법은 직접도말검사와 배양검 사를 수행하여 형태학적, 생물학적 성상을 통해 동정하였고 형 태학적 검사가 어려울 경우 urease 검사 및 모발천공검사를 이 용하여 동정하였다. 그러나 곰팡이 균주는 계대배양 시 형태의 변화를 가져오기에 향후에는 PCR기법을 통해 좀 더 정확한 균 종간의 동정이 필요할 것으로 생각된다. 이에 동물유래 피부사 상균을 대상으로 PCR기법을 이용하여 균종을 DNA 성상의 차 이로 감별하고자 하였으며 일부 균종간의 DNA band 확인을 수 행하였으나 일부 균종만 동정이 가능하였기에 향후 더 정확한 염기서열의 데이터 베이스가 구축된다면 동물친화성 피부사상 균도 PCR기법으로 동정이 가능할 것이다[6,20,21]. 앞서 연구 자들에 의해 1993년부터 동물친화성 피부사상균 감염의 보고 를 수행하였으며 본 연구에서도 이와 연계하여 2010-2016년 까지 감염을 보고하였다. 이는 지속적인 자료수집을 통해 향후 동물친화성 피부사상균 감염의 보고 시 기초 자료로 유용할 것 으로 사료된다.

\section{요 약}

2010 2016년에 병원을 내원한 환자를 대상으로 분석 결과 전체 분리균은 인체 친화성 감염환자는 33,575 명으로 $37.24 \%$ 가 분리되었으며 동물친화성 감염환자는 334 명으로 $0.37 \%$ 가 분리되었다. 토양친화성 감염환자는 30명으로 $0.03 \%$ 가 분리 되었고 그 외에 배양이 되지 않거나 오염균이 56,217 명(62.35\%) 으로 분리되었다.

동물친화성 피부사상균을 대상으로 남녀 성별에 따른 분포 를 살펴 본 결과 T. mentagrophytes는 남자(51.1\%), 여자 (48.9\%)가 분리되었기에 성별에 연관성이 거의 없었으나 $T$. verrucosum은 남자(38.9\%)에 비해 여자(61.1\%)가 다소 높게 분리되었다. M. canis는 남자(23.7\%)에 비해 여자(76.3\%)가 분 리율이 높게 나타났다.

연령에 따른 분석 결과 T. mentagrophytes는 50대(26.4\%), 60대(16.1\%)에 높게 분리되었고 T. verrucosum은 50대 (27.8\%), 60대(16.7\%), 그리고 10대 미만(16.7\%)의 순서로 분 포하였다. M. canis는 10대 미만(19.4\%), 10대(22.0\%), 그리고 20대(15.0\%)의 순서로 분리되었다.

계절에 따른 분석 결과 T. mentagrophytes는 봄(34.1\%), 겨 울(29.5\%)에 높게 분리되었고 T. verrucosum은 봄(44.4\%), 겨 울(27.8\%)에 높게 분리되었다. M. canis는 봄(18.9\%), 여름
(27.2\%), 가을(25.9\%), 그리고 겨울(28.1\%)에 비슷하게 분리되 었다. 이는 T. mentagrophytes와 T. verrucosum은 계절에 따 라 연관성을 보이나 M. canis는 계절에 따른 연관성이 나타나지 않았다.

부위에 따른 분석 결과로 T. mentagrophytes는 얼굴 (28.4\%), 팔(25.0\%)에서 높게 분리되었으며 T. verrucosum도 얼굴(38.9\%), 팔(27.8\%)에서 높게 분리되었다. 그러나 M. canis 는 다소 다양하게 머리(24.5\%), 팔(21.5\%), 얼굴(15.8\%), 등 (12.7\%) 등의 순으로 분리되었다.

임상 질환별 분석 결과 T. mentagrophytes는 몸백선증 (48.9\%)이 많이 분리되었고 다음으로 얼굴백선증(28.4\%), 수 부백선증(11.4\%)으로 분리되었다. T. verrucosum는 몸백선증 (55.6\%)이 가장 많이 분리되었고 얼굴백선증(38.9\%)이 분리되 었다. M. canis는 몸백선증(54.4\%)이 가장 많이 분리되었고 두 부백선증(24.5\%), 얼굴백선증(15.8\%)의 순서로 분리되었다.

본 조사를 통해 동물친화성 감염의 분포의 변화를 확인하였 으며 향후 지속적인 자료수집을 통해 동물친화성 감염의 분포 추이를 조사함에 도움이 될 것으로 사료된다.

\section{Acknowledgements: None \\ Funding: None \\ Conflict of interest: None}

\section{REFERENCES}

1. Bang YJ, Kim SY. Epidemiologic study on zoophilic dermatophytes. Korean J Clin Lab Sci. 2005;37(2):118-122.

2. Bang YJ, Kim SY, Park JS. An epidemiologic study on zoophilic dermatophytes in Daegu area from 2005 to 2009. Daegu Health College Collection of Learned Papers. 2011;31(1): 687-698.

3. Lee YW, Lim SH, Yim SM, Choe YB, Ahn KJ. A clinical and mycological study of dermatophytosis associated with animal contact. Korean J Med Mycol. 2005;10(4):151-159.

4. Jang YN. The Companion Animal Industry had grown more due to single person, elderly and internet users. The Livestock Farming. 2017;40(2):72-74.

5. Havlickova B, Czaika VA, Friedrich M. Epidemiological trends in skin mycoses worldwide. Mycoses. 2008;51(4):2-15.

6. Kim WJ, Kim JG, Choi JH, Shin DH, Choi JS, Kim KH, et al. Classification and typing of Trichophyton mentaprophytes isolated from a Korean population. Korean J Med Mycol. 2017; 22(1):1-13.

7. Nenoff P, Handrick W, Kruger C, Vissiennon T, Wichmann K, Graser Y, et al. Dermatomycoses due to pets and farm animals. Hautarzt. 2012;63(11):848-858.

8. Chermett R, Ferreiro L, Guillot J. Dermatophytoses in animals. Mycopathologia. 2008;166:385-405. 
9. Seebacher C, Bouchara JP, Mignon B. Updates on the epidemiology of dermatophyte infections. Mycopathologia. 2008: 166(5-6):335-352.

10. Bang YJ, Lee GS, Kim SY. Isolation of Microsporum canis from Tinea capitis of during treatment with Itraconazole. Korean J Clin Lab Sci. 2001;33(2):91-94.

11. Bang YJ, Kim SY. Isolation of dermatophytes from domestic animals and bed room dust of Tinea patients. Korean J Clin Lab Sci. 2006;38(2):94-98.

12. Choi WP, Yun SW, Song TC, Lee CS, Kim YU, Park CC. Studied on the canine ringworm by Microsporum canis and carrier state of dermatophytes in canine and feline. Korean J Vet Res. 1993;33(2):235-239.

13. Czaika VA, Lam PA. Trichophyton mentagrophytes cause underestimated contagious zoophilic fungal infection. Mycoses. 2013;56(1):33-37.

14. Lim SH, Houh D, Park HJ, Baek SC, Byun DG. Clinical and mycological studies of dermatophytosis in human transmitted from infected rabbits. Korean J Med Mycol. 2000;5(4):160-162.

15. Choe YS, Park BC, Lee WJ, Jun JB, Suh SB, Bang YJ. The clinical observation of Trichophyton verrucosum infections during the last 19 years (1986 2004). Korean J Med Mycol. 2006;11(2):
45-53.

16. Roh PU, Ryu JK, Bang YJ. Epidemiologic study on zoophilic dermatophytes in Kyongsang province area. J Prev Vet Med. 1996; 20(2):141-146.

17. Jang SH, Yun SJ, Lee JB, Kim SJ, Lee SC, Won YH. Clinical study of dermatophytosis caused by Microsporum canis. Korean J Med Mycol. 2014;19(2):39-44.

18. Gallo MG, Lanfranchi P, Poglayen G, Calderola S, Menzano A, Ferroglio E, et al. Seasonal 4-year investigation into the role of the alpine marmot(Marmota marmota) as a carrier of zoophilic dermatophytes. Med Mycol. 2005;43(4):373-379.

19. Sadeghi Tafti H, Falahati M, Kordbacheh P, Mahmoudi M, Safara M, Rashidian S, et al. A survey of the etiological agents of scalp and nail dermatophytosis in Yazd, Iran in 2014-1015. Curr Med Mycol. 2015;1(4):1-6.

20. Kim D, Jeoung SY, Ahn SJ. Molecular phylogenetic classification of dermatohphytes isolated from dogs and cats. J Vet Clin. 2006;23(4):405-410.

21. Kim YW, Yeo SG, Choi WP. Detection of DNA from dermatophytes by polymerase chain reaction. Korean J Vet Res. 2002;42(3):363-370. 